\title{
The evolution of the federal funding policies for the public health surveillance component of Brazil's Unified Health System (SUS)
}

\author{
Evolução da Política Federal de Financiamento \\ do Componente de Vigilância em Saúde no Brasil \\ após a criação Sistema Único de Saúde (SUS)
}

Vitor Laerte Pinto Junior ${ }^{1}$

José Cerbino Neto ${ }^{2}$

Gerson Oliveira Penna ${ }^{3}$
${ }^{1}$ Programa de

Epidemiologia e Vigilância

em Saúde, Fiocruz Brasília.

Campus Universitário Darcy

Ribeiro Gleba A SC4, Asa

Norte. 70910-900 Brasília

DF Brasil.

vitorlaerte@fiocruz.br

${ }^{2}$ Instituto Nacional de

Infectologia Evandro

Chagas.

${ }^{3}$ Núcleo de Medicina

Tropical, Universidade de

Brasília.
Abstract Health surveillance (HS) is one of the key components of the Brazilian Unified Health System (SUS). This article describes recent changes in health surveillance funding models and the role these changes have had in the reorganization and decentralization of health actions. Federal law no. 8.080 of 1990 defined health surveillance as a fundamental pillar of the SUS, and an exclusive fund with equitable distribution criteria was created in the Basic Operational Norm of 1996 to pay for health surveillance actions. This step facilitated the decentralization of health care at the municipal level, giving local authorities autonomy to plan and provide services. The Health Pact of 2006 and its regulation under federal decree No. 3252 in 2009 bolstered the processes of decentralization, regionalization and integration of health care. Further changes in the basic concepts of health surveillance around the world and in the funding policies negotiated by different spheres of government in Brazil have been catalysts for the process of HS institutionalization in recent years. Key words Federal government funding, National health surveillance policy
Resumo A Vigilância em Saúde (VS) é um dos componentes do Sistema Único de Saúde (SUS). Este artigo tem o objetivo de descrever as mudanças recentes no financiamento da VS e o seu papel na organização e descentralização das ações de saúde. A Lei 8080/1990 estabeleceu a VS como eixo estruturante do SUS e a criação de um teto financeiro exclusivo para as ações de VS na Norma Operacional Básica do SUS 1/96, composto por critérios equitativos, o que facilitou a descentralização das ações para a esfera municipal, permitindo ao gestor o planejamento e a continuidade das ações. O Pacto pela saúde, em 2006, e a sua regulamentação pela Portaria GM no 3252/2009 aprofundou a descentralização, a territorialização e a integralidade da atenção. As mudanças de conceituação da VS e a política de financiamento pactuada pelas esferas de governo foram catalisadoras para o processo de institucionalização da Vigilância em Saúde (VS) nos últimos anos no Brasil.

Palavras-chave Financiamento federal governamental, Política Nacional de Vigilância em Saúde 


\section{Introduction}

In the last fifteen years a profound change has taken place in the planning and implementation of public health surveillance (PHS) in Brazil. This can be observed through the efforts made to integrate surveillance with primary health care, a key step to implement the principle of integrality envisaged for the Unified Health System (SUS). The development of funding policies tied to the achievement of goals defined by the Tri-partite Management Commission (CIT) ${ }^{1}-$ a body of municipal, state and federal representatives that defines the rules of shared management of the SUS - has been an important instrument used throughout this period.

The ideals for public health care outlined in the Brazilian Constitution of 1988 were operationalized through legislation 8080/90 and $8142 / 90^{2,3}$, documents that define the guidelines and the funding sources of the SUS. In the more than 20 years that the SUS has been in existence, its trajectory has been constantly revised. The funding policies of the system have consistently sought to promote the primary objective of decentralizing health care services to the municipal level and defining the responsibilities of each level of government in order to guarantee universal access to care ${ }^{4,5}$.

The concept of public health surveillance and its insertion into the health system has come from international influences as well as social demands voiced through the system itself ${ }^{6,7}$. The evolution of these concepts stimulated the search for specific funding mechanisms beginning with the 1.996 SUS Basic Operational Norm (NOBSUS $96)^{8}$, continuing with federal decree № 1.172 of 2.004 and culminating in the changes promoted by the 2006 Health Pact and by the federal decree No 3.252 of $2009^{9}$.

The objective of this study is to analyze the evolution of policies instituted to funding public health surveillance in Brazil in the post-constitutional period. The decisions that led to changes in funding modalities came from the three levels of government through negotiations and establishment of pacts on goals and interventions. The catalyzing role of the Federal Ministry of Health $(\mathrm{MoH})$ and the participation of the National Council of State Health Secretaries (CONASS) and the National Council of Municipal Health Secretaries (CONASEMS) helped to strengthen health surveillance decentralization. This, in turn, fostered the constitutional principles of equity and integrality, and ensured a higher prior- ity for municipalities as the main level of health provision.

\section{Public Health Surveillance after the 1988 constitution}

With the advent of the SUS under federal law No $8.080 / 1.990$, efforts to decentralize the services and responsibilities of the National Epidemiological Surveillance System (SNVE) were intensified among health authorities at all three levels of government. This legislation also defined epidemiological surveillance as a "set of services that promote the knowledge, detection or prevention of any change in the determinant factors of individual or collective health, with the aim of recommending and adopting measures to prevent and control diseases or other injuries". In this law, the term epidemiological was still used to modify surveillance and the Sanitary Surveillance was considered as a separated branch, as addressed in a subsequent paragraph.

At the beginning of the 1990s, responsibility for the management of the SNVE was given to the recently created National Health Foundation (Funasa). This Foundation took over the activities of a series of extinct agencies - the National Secretariat of Basic Health Care (SNABS), National Secretariat of Special Health Programs (SNPES), Special Public Health Service Foundation (FSESP) and Superintendence of Public Health Campaigns (SUCAM) ${ }^{10}$. To this new Institution was designated the coordination of the decentralization process of funding and attributions of HS, oriented initially by the NOBSUS 1.993/1.996 and Funasa decree No 1.883 of $1.993^{11}$, and subsequently reviewed by $\mathrm{MoH}$ decree No 1.399 of $1.999^{12}$. Based on these guidelines, the management and formulation of national epidemiological surveillance activities were conducted by the National Epidemiology Center (CENEPI), linked to the Funasa. To assist the CENEPI in drawing up epidemiological guidelines and strategies, an Epidemiological Advisory Committee was created and filled by representatives of the national scientific community ${ }^{13}$.

During this period intensive discussions about the insertion of health surveillance into the field of public health took place nationally. In a 1998 article from Teixeira et al. ${ }^{7}$ a series of proposed models were discussed, showing the dichotomy between the disease-based model that was dominant at the time and others that widened the scope of surveillance activities to go beyond the clinical and epidemiological definitions at 
the individual and collective levels to include social definitions that affect distinct population groups due to their life conditions.

The restructuring of epidemiological surveillance at the federal level - still divided in departments of the $\mathrm{MoH}$ and Funasa at the time - began in 2003 with the transformation of the CENEPI into a Secretariat of Health Surveillance (SVS), directly linked institutionally to the $\mathrm{MoH}$. With this step, Funasa was no longer responsible for the management and transfer of epidemiological surveillance funds to the states and municipalities or for overall disease control which had also been transferred to the new Secretariat.

Under this new proposal, made official under $\mathrm{MoH}$ decree $\mathrm{N}^{\circ} 1.172$ of $2.004^{14}$, the change from 'epidemiological surveillance' to 'health surveillance' was adopted in accordance with discussions and the redefinition of terms that took place nationally and internationally $y^{7,15,16}$. The challenge to this new structure was to address and consolidate the services of environmental surveillance, occupational health, health situation analysis, and especially Sanitary Surveillance within the three levels of SUS management.

With the publication of federal decree $\mathrm{N}^{\mathrm{O}}$ 3.252 of $2.009^{9}$, which was the result of joint discussions between federal, state and municipal health authorities and the National Agency of Sanitary Surveillance (Anvisa), health/sanitary inspection services were included in the scope of health surveillance. This strengthened the directives for integrality of health care which presupposes the integration of health surveillance with primary health care (PHC).

\section{The decentralization process of health surveillance funding}

Along with the progressive implementation of the SUS, health surveillance was also incorporated into decentralization process. Prior to the NOBSUS 96 and federal decree $\mathrm{n}^{\circ} 1.399 / 1.999^{12}$, funding of health surveillance was carried out through ad hoc programs using various finance mechanisms or direct transfers. This mechanism prevented the planning of the routine activities and was directed to situations of epidemics or worsening of epidemiological profile ${ }^{17}$.

The promulgation of NOBSUS 1996 and its subsequent regulations established a modality of funding exclusive to health surveillance with the creation of the Epidemiology and Disease Control Financial Ceiling (TFECD). This mechanism allowed for three types of funding: regular and automatic transfers from one level of government to another; remuneration of rendered services; and direct transfers from the National Fund of Health (FNS) to state or municipal funds (fund to fund transfers), which were quite limited at the time.

The TFECD represented a significant advance in SUS funding policies given that the principles of regionalization and equity were built into its design and it used the redistributive power of the federal government to strengthen these principles. The composition of this ceiling was based on factors such as regional differences in epidemiological characteristics and local difficulties in conducting HS activities, mainly those with high economic impact in consequence of the costs of controlling some endemic diseases.

For the operationalization of the TFECD, Brazilian states were classified into three strata: stratum 1, composed of the states in the Northern region where endemic disease control programs (malaria, dengue fever, etc.) required more expensive field interventions; stratum 2, covering the North-eastern, Mid-western (except the Federal District) and South-eastern (except São Paulo) states with considerable areas of dengue fever incidence as well as persistent endemic diseases such as leishmaniasis and Chagas disease; stratum 3 was formed by the states of Rio Grande do Sul, Santa Catarina, Paraná, São Paulo and the Federal District (Brasília) that enjoyed a more developed socioeconomic profile ${ }^{17}$. Later, a fourth stratum would be created under $\mathrm{MoH}$ decree No 1.172 in $2.004^{14}$ with only the states of Rio Grande do Sul and Santa Catarina and the Federal District.

The TFECD was calculated by adding three components: a variable amount per capita based on the state's stratum multiplied by its total population; an amount per $\mathrm{km}^{2}$ multiplied by the total land area; and a decentralization incentive equally distributed for all four strata. It was also defined that a counterpart contribution would be made by the states and municipalities between $20-40 \%$ of the amount of the transferred TEFCD, depending on the classification of the state, so as to induce a direct contribution of those federal entities to the funding of the actions.

$\mathrm{MoH}$ decree $\mathrm{N}^{\circ} 950$ of $1.999^{18}$, published soon afterwards, defined the annual amounts per capita and per $\mathrm{km}^{2}$ to calculate the monthly federal transfers of the TFECD to the state and municipal levels at $1 / 12$ of the established amount. This upheld the principles of decentralized care and establishment of a single point of authority 
at each level of government. Table 1 outlines the resources of the Fund for the entire country under the final update of $\mathrm{MoH}$ decree $\mathrm{No} 8 / 2004^{19}$.

The decentralization of health surveillance with the direct and regular transfer of resources led to the need for creation of a tool to help define the activities to be carried out and goals to be reached. To this end, it was created the Integrated Epidemiology and Disease Control Plan and Pact (PPI-ECD) which should be done by state and municipal health secretaries. The Bi-partite Management Commissions (CIB) - established in the NOBSUS 93 as a forum for agreements between state and municipal secretaries ${ }^{20}$ - would determine the amount to be transferred to each federal entity under their management, taking into account the local epidemiological specificities. Following the approval of the PPI-ECD by the CIT at the federal level, resources were decentralized through fund to fund transfer.

The transfer of funds by the FNS was conditioned upon the fulfillment of the goals agreed in the PPI-ECD and upon the attesting the execution of health surveillance actions under the responsibility of each sphere of governance. The objective of the PPI-ECD was to establish a set of activities and goals for disease control as well as to stimulate the development of health surveillance at the state and municipal levels. The national parameters of this instrument are defined by technicians in the Health Surveillance Working Group (GTVS) that represent the three levels of government. The origin of the GTVS dates back to the Epidemiological Advisory Committee created at the time of the CENEPI ${ }^{13}$.

In order for the states and the Federal District to receive these transfers on a regular basis, it was necessary to present a finalized PPI-ECD and meet other bureaucratic requirements. These included providing proof of the required infrastructure and an adequate team as well as a for- mal request sent to the Funasa, which presented the request to the CIT for approval. For the municipalities, in addition to the requirements of state governments, it was also necessary the qualification in one of the management modalities of the health system according to the NOBSUS 96 and the subsequent approval by the state health secretariat and the CIB.

In 2001 and 2002 the Operational Norms for Health Services of the SUS were published (NOAS SUS) ${ }^{21,22}$. These regulations had the objective of reorganizing the network of care in a more hierarchized and regionalized way, and represented important instruments in the inter-municipality and inter-state discussions to redefinition of functional regional care networks. Regarding surveillance, these documents brought little contribution to the regionalization and integration of HS into the care networks.

As a consequence SVS creation, a new regulation of the NOBSUS 96 was published in 2.004 as $\mathrm{MoH}$ decree $\mathrm{No}^{\circ} 1.172^{14}$. This scenario provided the institutional environment for the discussion and promotion of health surveillance decentralization at other levels of SUS management, therefore becoming more closely aligned to what was practiced in health care services. This decree effectively incorporated epidemiology and disease control into the broader concept of health surveillance, as a consequence the denomination PPI-ECD also changed to Health Surveillance Integrated Plan and Pact (PPI-VS).

The roles and responsibilities of each level of government were again clarified, reinforcing the shared management of the system by the three levels of government. Nevertheless, each level had its specific functions in the system, attributed; to the national level the police maker function; to the state level the management of its municipalities HS system when necessary; and the municipalities held the responsibility of, among other

\begin{tabular}{|c|c|c|c|c|}
\hline Level & $\begin{array}{l}\text { TFVS - state per capita } \\
\text { (R\$/person/year) }\end{array}$ & $\begin{array}{r}\text { TFVS - state by land } \\
\text { area }\left(\mathrm{R} \$ \mathrm{x} \mathrm{Km^{2 }}\right)\end{array}$ & $\begin{array}{c}\text { Decentralization } \\
\text { incentive }(\mathrm{R} \$ / \text { person/yr.) }\end{array}$ & $\begin{array}{c}\text { Counterpart SMS } \\
(\text { munic. })+\text { SES }(\text { state })(\%)\end{array}$ \\
\hline 1 & 4.23 & 3.00 & 0.48 & 20 \\
\hline 2 & 2.98 & 2.04 & 0.48 & 30 \\
\hline 3 & 1.88 & 1.20 & 0.48 & 35 \\
\hline 4 & 1.84 & 1.20 & 0.48 & 40 \\
\hline
\end{tabular}

Source: Joint decree Executive Secretariat/Health Surveillance Secretariat No. 8/2004. SMS: Municipal Health Secretariat; SES: State Health Secretariat; TFVS: Health Surveillance Fund (which substituted the Epidemiology and Disease Control Fund as per MoH decree $\left.{ }^{\circ} 1.172 / 2004\right)$. 
In consonance with the National Health Plan, approved under decree No 2.607 of $2.004^{24}$, a "Health Pact" was developed and disseminated as part of $\mathrm{MoH}$ decree 399 in $2.006^{25}$. The main objectives of this Pact were to reinforce the management decentralization through the regionalization of health services, respecting the locals specificities (social, political, administrative and epidemiological), and to overcome the fragmentation of health policies and programs. The Pact included changes in the certification mechanisms previously established by the NOBs (full management of primary care or full management of the complete system), which was substituted by the adherence of health managers to the Pact, reinforcement of the creation of health regions and the institution of Regional Management Councils (CGR).

At the time of the Pact's publication, the federal entities were in the situations described below:

a) 26 states, the Federal District (Brasília) and 3.151 municipalities certified for health surveillance management and agreed to the Pact;

b) 17 municipalities uncertified for health surveillance management but still agreed to the Pact;

c) 2.244 municipalities certified for health surveillance management but not agreed to the Pact;

d) 152 municipalities uncertified for health surveillance management and not agreed to the Pact;

Regarding the 17 municipalities that agreed to the Pact but not certified for HS management, there was a regulation regarding the transfer of resources from the Health Promotion and Surveillance Component that came about through the publication of specific decrees, as deliberated by the CIB of each state.

Thus, the evolution of this process of reducing the bureaucratic exigencies, allowed that the majority of municipalities to be certified, so that, 4.479 municipalities had already agreed to the pact with the approval of CIT until December 2011.

The guidelines that determine the responsibility of each level of government for funding of health care services was also reinforced. The direct transfer mechanisms were strengthened through the reorganization of funding into five major blocks to cover health system expenditures: primary (basic) care, secondary/tertiary care, health surveillance, pharmaceutical assistance and SUS management.

Federal decree No 204 of 2.007 regulated the financial structure and resource transfers using these blocks ${ }^{26}$ according with mechanisms already in place. The health surveillance block was subsequently divided into two components: Epidemiological Surveillance (ES) and environmental health and Sanitary Surveillance. The ES/ environmental health component is composed of the Health Surveillance Funding Ceiling TFVS - as well as the following incentives: hospital-based epidemiological surveillance; public health laboratories; health promotion activities; population-based cancer registration; vital records/death certification; vaccination campaigns; monitoring of Aedes aegypti resistance to insecticide; hiring of field health workers; STD/AIDS; and others that may be instituted through specific normative decrees.

The health surveillance block had its regulations changed by the $\mathrm{MoH}$ decree No 3.252 of $2.009^{9}$ and it was separated into two components: Component of Health Surveillance and Health Promotion and Component of Sanitary Surveillance. These two components are interchangeable, increasing the flexibility for resource utilization and integration between these two areas. The Component of Health Surveillance and Health Promotion is geared towards the prevention and control of diseases, and is financed by two funding floors: the Fixed Health Promotion and Surveillance Funding Floor (PFVPS) and the Variable Health Promotion and Surveillance Funding Floor (PVVPS) (Figure 1).

The PFVPS substituted the TFVS but is calculated in the same way: a fixed amount per capita based on the stratification and territory of each state in the federation. Following the definition of the totals per state, at least $10 \%$ of the total must be transferred to the state government and added of the Incentive for Public Health Central Laboratories (FINLACEN). The amount equivalent to at least $60 \%$ of the total calculated amount goes to the municipalities and at least $80 \%$ should be sent to the states' capital and to the municipalities that belongs to metropolitan areas. An adjustment of these totals is carried out annually based on population estimates made by the Brazilian Institute of Geography and Statistics 
(IBGE) for the year in question, what eliminates subjective transfer criteria. Graph 1 illustrates the growth of the PFVPS in the last ten years.

The other sub-component of this block, the PVVPS, is made up of specific incentives that are transferred based on whether a determined program or activity has been implemented or in the case of special epidemiological needs; specific norms are created for these ends (Chart 1).

The annual vaccination campaigns against the seasonal flu, polio and rabies are funded through specific agreements by the CIB whereby resources are transferred directly through the PFVPS. In the case of the Federal District, which is not subdivided into other municipalities, $100 \%$ of the amount of the PFVPS is transferred along

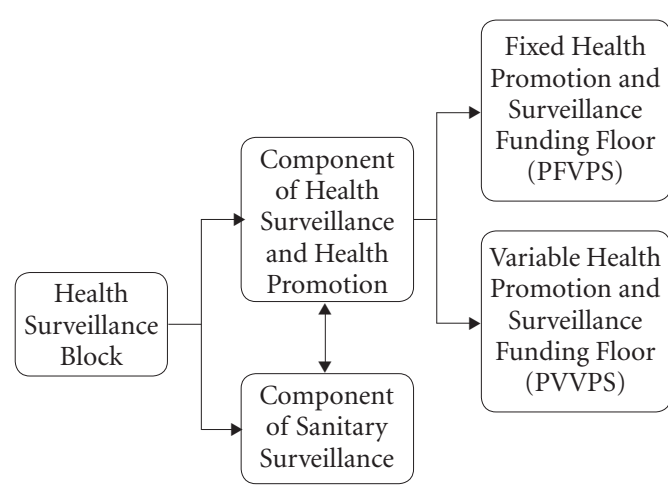

Figure 1. Schematic representation of the Blocks of Health Surveillance Funding and their subdivision. with the relevant amounts for the FINLACEN and aforementioned campaigns.

The resources in the PFVPS and PVVPS are transferred directly from the federal level to public accounts in the states and municipalities. In order that each health secretariat receives funding in a timely manner, it is necessary to be enrolled in the Health Pact and be up to date with routine data entry into the Notifiable Diseases Information System (SINAN), Live Birth Information System (SINASC) and the Mortality Information System (SIM) ${ }^{9}$.

Prior to federal decree No 3.252 of $2.009^{9}$, resource transfer was done in twelve monthly installments, but the small municipalities were in disadvantaged by this division of funding since the amounts received were inferior to what was

Chart 1. Other funding components of health surveillance services (PVVPS).

\begin{tabular}{|l|}
\hline Support homes for adults living with HIV/AIDS \\
\hline Hospital epidemiology units - NHE \\
\hline Vital records unit (death certification) - SVO \\
\hline Cancer registration system (population) - RCBP \\
\hline Infant formula for children exposed to HIV \\
\hline $\begin{array}{l}\text { Incentives for the National Program of HIV/AIDS } \\
\text { and other STDs }\end{array}$ \\
\hline Health Promotion \\
\hline
\end{tabular}

Source: Ministery of Health, Decree 3.252, December 2009.

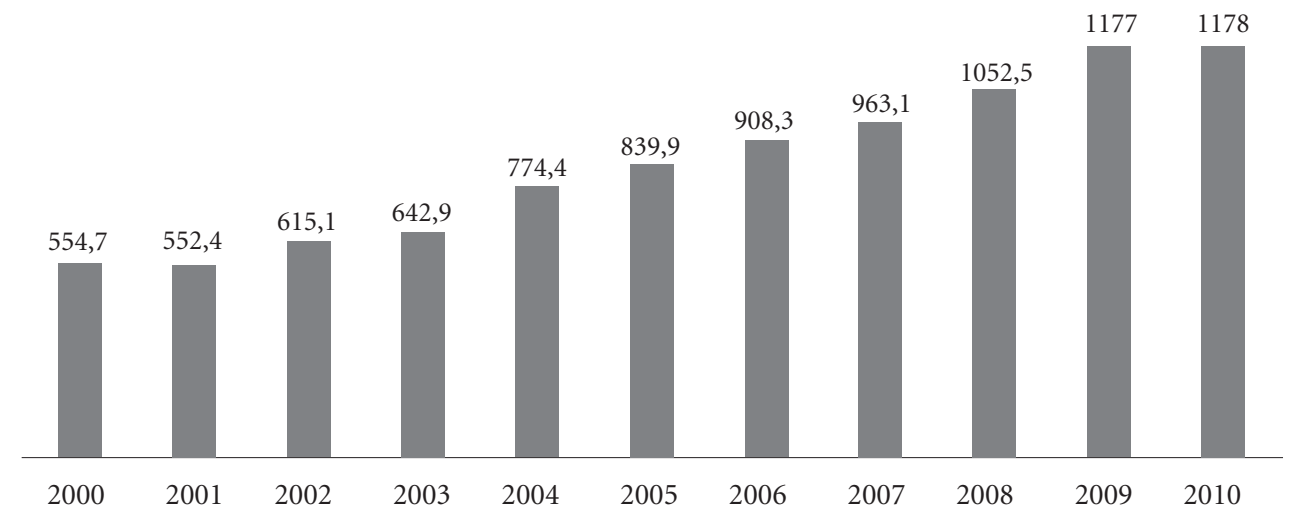

Graph 1. Evolution of the Fixed and Variable Health Promotion and Surveillance Funding Floors (previously known as the Health Surveillance Funding Ceiling), 2000-2010. 
needed for health surveillance activities. Municipal officials were required to wait for subsequent installments so as to accumulate sufficient funds to carry out basic interventions. This often also led to the suspension of transfers due to a lack of funding utilization during the first six months after the transfer. This problem was resolved by reducing the number of installments from twelve to three per year.

The resources destined for health surveillance must be used exclusively for this end and in accordance with the Health Surveillance Action Plan (PAVS) that substituted the PPI-VS in $2009^{27}$. The PAVS sought to guide the insertion of health surveillance services into the Annual Health Plan (PAS) and the responsibility for planning was therefore transferred to the Municipal Health Secretariats. This allowed the prioritization of the execution of the Pact goals at the local level, taking into consideration municipal priorities and integrality of health services. The outcomes of interventions planned in the PAVS should be included in the Annual Management Report (RAG), as required by $\mathrm{MoH}$ decree $\mathrm{N}^{\circ}$ 3.176 of $2.009^{28}$.

The municipalities that did not agree to the Health Pact and were not certified for health surveillance management have these services carried out by the state government. These municipalities also have their transfers blocked if health authorities do not meet the monthly obligation of updating the aforementioned health information systems for two consecutive months. Transfers are only released following proof of completion of full data entry ${ }^{9}$.

\section{Discussion}

Upon reviewing the evolution of health surveillance finance policies, it is possible to see that this closely followed a similar evolution in the concepts of epidemiological surveillance in Brazil. This movement has increasingly clarified the roles and responsibilities of each level of government in the national HS system, similarly strengthening the process of developing tri-partite agreements ${ }^{9,16}$.

The definition of health surveillance finance policies was essential for beginning the process of consolidating HS as a pillar of the SUS. In ad- dition to the increased resources allocated to surveillance services, there was an improvement in the calculation mechanisms. These tools allowed the incorporation of demographic, political and epidemiological differences as criteria for funding calculation, which led to further equity in the resource transfer process. They also allowed the creation of clearer goals to the federal entities so as to assist the states and municipalities in the planning and evaluation of HS actions for which they were responsible.

In addition to the principle of equity, decentralization was accelerated by the design and implementation of finance policy. This was one of the instruments used to carry out the reorganization of the SUS through the clear definition of responsibilities at each level of government and the strengthening of the regionalization process ${ }^{29}$.

The Health Pact improved the capacity of municipalities and states to manage health surveillance, demonstrated by 2011 statistics that show that only $1.96 \%$ of all municipalities were not officially responsible for health surveillance in their area of coverage. The alignment of the health surveillance criteria and competencies with those practiced in primary health care was a strategic step to increase the number of municipalities committed to the policies jointly agreed by the three levels of government. This led to the planning of municipal HS services considering the territory level (widening the scope of the regional health networks), the integrality of health care and the integration with primary health care services.

The evolution of health surveillance finance policies has gone hand in hand with the key principles on which the SUS was founded: universality, equity, decentralization to a single point of command at each level of government, regionalization of different levels of health care complexity, and popular participation. The funding mechanisms of the SUS which used to be highly centralized have become a joint construction among the federal, state and municipal governments consolidating dozens of funds and accounts into the five funds that currently exist. To advance more in the full achievement of these principles, more work needs to be done to establish a single fund that simultaneously improves the processes of control and evaluation at each level of government. 


\section{Collaborations}

VL Pinto Junior conceived and worked in the writing and revision of the manuscript. J Cerbino Neto worked in the research, in writing and revision of the manuscript. GO Penna work in the writing and final revision of the manuscript.

\section{References}

1. Brasil. Ministério da Saúde (MS). Conselho Nacional de Secretarias Municipais de Saúde (CONASEMS). O SUS de A a Z, garantindo saúde nos municípios. $3^{\text {a }}$ ed. Brasília: Editora do Ministério da Saúde; 2009.

2. Brasil. Lei n ${ }^{\circ} 8.080$, de 19 de setembro de 1990. Dispõe sobre as condições para a promoção, proteção e recuperação da saúde, a organização e o funcionamento dos serviços correspondentes e dá outras providências. $D i-$ ário Oficial da União 1990; 20 set.

3. Brasil. Lei no. 8.142, de 28 de dezembro de 1990. Dispõe sobre a participação da comunidade na gestão do Sistema Único de Saúde - SUS e sobre as transferências intergovernamentais de recursos financeiros na área da saúde e dá outras providências. Diário Oficial da União 1990; 31 dez.

4. Levcovitz E, Lima LD, Machado CV. Política de saúde nos anos 90: relações intergovernamentais e o papel das Normas Operacionais Básicas. Cien Saude Colet 2001; 6(2):269-291.

5. Mendes A, Marques RM. O financiamento do SUS sob os "ventos" da financeirização. Cien Saude Colet 2009; 14(3):841-850.

6. Teutsch $S$, Thacker S. Planning a public health surveillance system. Epidemiol Bull 1995; 16(1):1-6.

7. Teixeira CF, Paim JS, Vilasbôas AL. SUS, modelos assistenciais e vigilância da saúde. Inf Epidemiol SUS 1998; 7(2):7-28.

8. Brasil. Ministério da Saúde (MS). Portaria n².203, de 5 de novembro de 1996. Aprova, nos termos do texto anexo a esta Portaria, a NOB 1/96, a qual redefine o modelo de gestão do Sistema Único de Saúde, constituindo, por conseguinte, instrumento imprescindível à viabilização da atenção integral à saúde da população e ao disciplinamento das relações entre as três esferas de gestão do Sistema. Diário Oficial da União 1996; 6 nov.

9. Brasil. Ministério da Saúde (MS). Portaria n 3.252, de 22 de Dezembro de 2009. Aprova as diretrizes para execução e financiamento de ações de Vigilância em Saúde pela União, Estados, Distrito Federal e Municípios e dá outras providências. Diário Oficial da União 2009; 23 dez.

10. Brasil. Presidência da República. Casa Civil. Decreto $n^{\circ}$ 100, de 16 de Abril de 1991. Institui a Fundação Nacional de Saúde, e dá outras providências. Diário Oficial da União 1991; 17 abr.

11. Brasil. Fundação Nacional de Saúde. Portaria n ${ }^{\circ} .1 .883$, de 16 de dezembro de 1993. Resolve que a descentralização das ações e serviços de saúde da Fundação Nacional de Saúde - FNS, como prioridade político-institucional. Diário Oficial da União 1993; 29 dez.

12. Brasil. Ministério da Saúde (MS). Portaria n 1.399, de 15 de Dezembro de 1999. Regulamenta a NOB SUS 01/96 no que se refere às competências da União, Estados, Municípios e Distrito Federal, na área de epidemiologia e controle de doenças, define a sistemática de financiamento e dá outras providências. Diário Oficial da União 1999; 16 dez. 
13. Brasil. Fundação Nacional de Saúde (FNS). Comissão Nacional de Epidemiologia (CENEPI). Relatório de Gestão - outubro de 1993 a dezembro de 1994. Brasília: Editora do Ministério da Saúde; 1994.

14. Brasil. Ministério da Saúde (MS). Portaria $\mathrm{n}^{\circ} 1.172$, de 15 de Junho de 2004. Regulamenta a NOB SUS 01/96 no que se refere às competências da União, Estados, Municípios e Distrito Federal, na área de Vigilância em Saúde, define a sistemática de financiamento e dá outras providências. Diário Oficial da União 2004; 16 jun.

15. Thacker SB, Berkelman RL. Public health surveillance in the United States. Epidemiol Rev 1988; 10(1):164190.

16. Paim JS. Modelos de Atenção e Vigilância da Saúde. In: Rouquayrol MZ, Gurgel M, organizadores. Epidemiologia \& Saúde. $6^{\mathrm{a}}$ ed. Rio de Janeiro: MEDSI; 2003. p. 567-571.

17. Silva Junior J. Epidemiologia em serviço: uma avaliação de desempenho do Sistema Nacional de Vigilância em Saúde [tese]. Campinas: Universidade Estadual de Campinas; 2004.

18. Brasil. Ministério da Saúde (MS). Portaria nº 950, de 23 de Dezembro de 1999. Define, na forma do Anexo I, os valores anuais per capita e por quilômetro quadrado, relativos aos recursos federais destinados à composição do Teto Financeiro e Epidemiologia e Controle de Doenças TFECD, de cada um dos estados previstos no art. 14 Portaria GM/MS n 1.399/99. Diário Oficial da União 1999; 24 dez.

19. Brasil. Ministério da Saúde (MS). Portaria Conjunta ${ }^{\circ}$ 8, de 29 de Junho de 2004. Define o Teto Financeiro de Vigilância em Saúde- TFVS e dá outras providências. Diário Oficial da União 2004; 12 jul.

20. Brasil. Ministério da Saúde (MS). Portaria nº545, de 20 de maio de 1993. Estabelece normas e procedimentos reguladores do processo de descentralização da gestão das ações e serviços de saúde, através da Norma Operacional Básica - SUS 01/93. Diário Oficial da União 1993; 24 maio.

21. Brasil. Ministério da Saúde (MS). Portaria n 95, de 26 de Janeiro de 2001. Aprovar, na forma do Anexo desta Portaria, a Norma Operacional da Assistência à SaúdeNOAS-SUS 01/2001 que amplia as responsabilidades dos municípios na Atenção Básica; define o processo de regionalização da assistência e dá outras providências. Diário Oficial da União 2001; 29 jan.

22. Brasil. Ministério da Saúde (MS). Portaria n. ${ }^{\circ}$ 373/GM, de 27 de fevereiro de 2002. Aprova, na forma do anexo desta portaria, a norma operacional da Assistência à saúde - NOAS-SUS 01/2002 que amplia as responsabilidades dos municípios na atenção básica; estabelece o processo de regionalização como estratégia de hierarquização dos serviços de saúde e de busca de maior equidade; cria mecanismos para o fortalecimento da capacidade de gestão do sistema único de saúde e procede a atualização dos critérios de habilitação de estados e municípios. Diário Oficial da União 2002; 29 fev.
23. Paim JS. Epidemiologia e planejamento: a recomposição das práticas epidemiológicas na gestão do SUS. Cien Saude Colet 2003; 8(2):557-567.

24. Brasil. Ministério da Saúde (MS). Portaria no 2.607, de 10 de dezembro de 2004. Aprova o Plano Nacional de Saúde/PNS - Um Pacto pela Saúde no Brasil. Diário Oficial da União 2004; $13 \mathrm{dez}$.

25. Brasil. Ministério da Saúde (MS). Portaria ${ }^{\circ} 399$, de 22 de Fevereiro de 2006. Divulga o Pacto pela Saúde 2006Consolidação do SUS e aprova as Diretrizes Operacionais do referido Pacto. Diário Oficial da União 2006; $23 \mathrm{fev}$.

26. Brasil. Ministério da Saúde (MS). Portaria ${ }^{\circ} 204$, de 29 de Janeiro de 2007. Regula o financiamento e a transferência dos recursos federais para as ações e os serviços de saúde, na forma de blocos de financiamento, com o respectivo monitoramento e controle. Diário Oficial da União 2007; 14 mar

27. Brasil. Ministério da Saúde (MS). Portaria no 3.008, de 1 de dezembro de 2009. Determina a Programação das Ações de Vigilância em Saúde (PAVS), como um elenco norteador para o alcance de metas do Pacto e demais prioridades de relevância para o Sistema Nacional de Vigilância em Saúde e Vigilância Sanitária, eleitas pelas esferas Federal, Estadual e Municipal. Diário Oficial da União 2009; 4 dez.

28. Brasil. Ministério da Saúde (MS). Portaria n 3.176, de 24 de dezembro de 2008. Aprova orientações acerca da elaboração, da aplicação e do fluxo do Relatório Anual de Gestão e quanto a informações sobre o Plano de Saúde. Diário Oficial da União 2010; 11 jan.

29. Arretche M. Federalismo e políticas sociais no Brasil: problemas de coordenação e autonomia. São Paulo Perspect 2004; 18(2):17-26.

Artigo apresentado em 03/05/2013

Aprovado em 23/07/2013

Versão final apresentada em 29/07/2013 
